\title{
Determining the locations of airports and passenger demand by evaluating accessibility and special properties: Case study of Turkey
}

\author{
Erişilebilirlik ve diğer özelliklerin değerlendirilerek havalimanları \\ yerlerinin ve yolcu taleplerinin belirlenmesi: Türkiye örneği
}

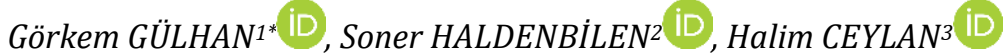 \\ ${ }^{1}$ Department of City and Regional Planning, Faculty of Architecture and Design, Pamukkale University, Denizli, Turkey. \\ ggulhan@pau.edu.tr \\ 2,3Department of Civil Engineering, Faculty of Engineering, Pamukkale University, Denizli, Turkey. \\ shaldenbilen@pau.edu.tr, halimceylan1968@gmail.com
}

\begin{abstract}
The accessibility of airports and the airport preference of users are significant criteria for the competitiveness of airports. When passengers choose a route, they actually expect the completion of the transportation chain and they want to travel to the door from the door. For this reason, the factors that affect the passenger's decision for a significant option go beyond the price and quality of air services. The decision for a specific air service and a particular airport depends on the accessibility of the airport to a considerable extent. Factors affecting the choice of the airport can simply be divided into two categories. The category that reflects the number of air fares, frequencies and served destinations is defined as "air side". The category of airport accessibility, namely access, is also called "land side". The locations of the airports are usually set up around the periphery of the city's with a reasonable length such as $50 \mathrm{~km}$. The access of the airports may affect the passenger demands, so this study investigate the Turkish airport coverage in length of 50, 75 and $100 \mathrm{~km}$ radius from city centers. The main purpose of this study thus investigates whether a new airport construction is needed or not for domestic flights. Results showed that if $100 \mathrm{~km}$ radius length is used as a criterion for building new airport, only 10 cities with total population of about 2.5 million people will be outside the airport access. Socio-economical features are highly related with the location choice of airports. Therefore, accessibility properties are compared with the special properties of the cities and possible new airport locations have been determined.
\end{abstract}

Keywords: Airport, Location choice, Accessibility

\section{Giriş}

The rapid change of the world and the progress of globalization have been directly and irrevocably affected many fields. Logistics, scope and efficiency have increased with the triggering of the developing technology [1]. Particularly fastpaced technology has led to an increase in transportation opportunities and accordingly the importance of more careful planning, integration and common use of transport systems has come to the forefront. The logistics approach, which is a new value in terms of competition, has become important in relation to transportation [2]. The least and most recently utilized subsystem within transportation systems is air transportation [3]. Airlines are a frequent choice of transportation system since they travel faster and are safer than other modes of transportation [4]. The time of travel between the start and the

\section{Öz}

Havaalanlarının erişilebilirliği ve kullanıcıların havaalanlarının tercihi, havaalanlarının rekabet edebilirliği için önemli kriterlerdir. Yolcular bir rota seçtiklerinde, aslında taşıma zincirinin tamamlanmasını beklemekte ve kapıdan kapıya seyahat etmek istemektedirler. Bu nedenle, yolcuların belli bir seçenek için kararını etkileyen faktörler, hava hizmetlerinin fiyat ve kalitesinin ötesine geçmektedir. Belirli bir hava hizmeti ve belirli bir havaalanı için verilen karar, havaalanının büyük ölçüde erişilebilir olmasına bağlıdır. Havaalanı seçimini etkileyen faktörler sadece iki kategoriye ayılmaktadır. Uçus ücretlerini, frekansları ve sunulan varış noktalarının sayısın yansitan kategori "hava tarafi" olarak tanımlanmaktadır. Havaalanına erişilebilirlik kategorisine de, yani erişime, "kara tarafi" denir. Havaalanlarının yerleri genellikle kentin çevresine $50 \mathrm{~km}$ gibi makul bir uzunlukta kurulmaktadır. Havaalanlarının erisimi yolcu taleplerini etkileyebilir, bu nedenle bu çalış̧ma, Türk havaalanlarının şehir merkezlerinden 50, 75 ve 100 km yarıçapı uzunluğunu araștırmaktadır. Bu çalıșmanın temel amacı, iç hat uçuşları için yeni bir havaalanı inşaatının gerekli olup olmadığını incelemektir. Sonuçlar, 100 km yarıçap uzunluğunun yeni bir havalimanı inșa edilmesinde bir kriter olarak kullanılması durumunda, toplam nüfusu yaklaşlk 2,5 milyon olan sadece 10 kentin havaalanına erișimin dıșında olacağını göstermistir. Sosyo-ekonomik özelliklerin havalimanlarının yer seçimi ile yakından ilgili olduğu görülmektedir. Bu nedenle erişilebilirlik özellikleri șehirlerin diğer özellikleri ile karşılaştırılmış ve olası yeni havalimanı yerleri belirlenmiştir.

Anahtar kelimeler: Havalimanı, Yer seçimi, Erișilebilirlik end of the journey made by air, the cost and comfort are influential on the choice of travel preference. The time of travel between the start and the end of the journey, the cost and the comfort are influential on the choice of travel recurrence. Accessibility (or access only) refers to products, services, activities and it represents the ease of access to destinations. It can also be defined as potential for interaction and mutual exchange [5]. For this reason, it is possible for airports to consider as accessible, with travel time and cost minimizing comfort and maximizing comfort.

The accessibility of airports and the airport preference of users are significant criteria for the competitiveness of airports. When passengers choose a route, they actually expect the completion of the transportation chain and they want to travel to the door from the door. For this reason, the factors that affect the passenger's decision for a particular option go beyond the 
price and quality of air services. The decision for a specific air service and a particular airport depends on the accessibility of the airport to a considerable extent [6].

Factors affecting the choice of the airport can simply divided into two categories. The category that reflects the number of airfares, frequencies and served destinations are defined as "air side". The category of airport accessibility, namely access, is also called "land side". In the past decades, several elements of airport accessibility have changed. Many airport operators across Europe have begun to see long-haul rail access as an important factor in expanding their sphere of influence. However, accessibility by car continues to play an important role as this type of transportation is still not dominated by the majority of the airports. With quality land transportation, some of the major airports have begun to turn into "airport cities". Here, real estate development facilities for inter-species functions, offices, shops and even residential areas were supported [6].

There are many researches such as Pels et al. [7],[8] for demand modelling and for multiple airport cities [9]-[14]. Derruder etc., has made a spatial analysis [15]. Additively, location choice of airports is a dynamic, multi-objective, mixed integerprogramming model that tries to find the optimal location under capacity and budgetary restrictions [16]. Concurrently, airport locations are analyzed in terms of role of land and airside accessibility [17]. Decision makers generally guided by the traditional concept of airport catchment area [12],[18],[19].

Aviation sector in Turkey is rapidly improving especially in last years [20]. Airport location choice in Turkey depends on Airport Planning Guide that is generated by International Civil Aviation Organization [21]. Factors that influence the location choice of airports in Turkey may be listed as, aviation operations, development of environmental, atmospheric conditions, access to land transportation, be able to enlargement, topography, environment and the existence of other airports and accessibility of services [22]. Assessing the relationship between population and accessibility and reflecting this correlation to site selection decisions is a factor that increases the accuracy of decisions.

In this study, 55 airport location choice decisions in Turkey are studied by of the Quantum Geographic Information System (QGIS) software in the axe of accessibility. Access roads of 50, 75 and $100 \mathrm{~km}$ circles are drawn on the map with the airports being in the center. Afterwards, the distances to the city centers and the periphery districts are evaluated. An accessibility analysis is performed for those three borders to assess which settlements are required an airport and passenger demand is predicted. Additionally, since socio-economical features are highly related with the location choice of airports, accessibility properties are compared with the special properties of the cities and possible new airport locations have been determined.

\section{Method and study area}

The preparation rules and the study area data are given below.

\section{$2.1 \quad$ Method}

The aim of this study is to determine the necessity of airports by considering accessibility measurements and passenger demand. For this purpose, a triple stepwise paradigm has offered and each level have defined in Figure 1.

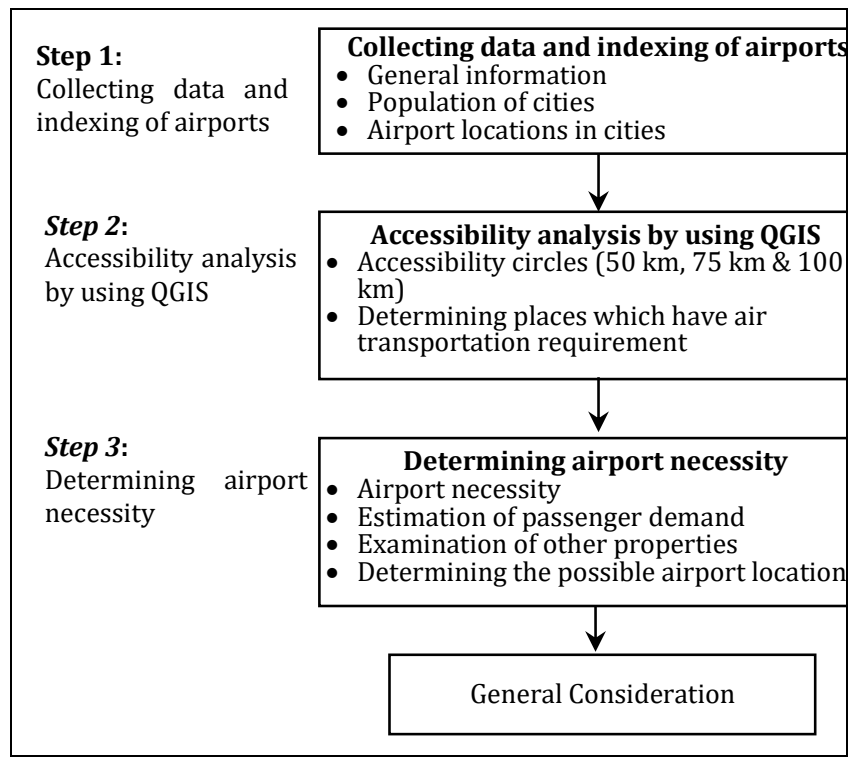

Figure 1: Flowchart of the stepwise paradigm

Step 1 starts with the obtaining data. Determination process of airport locations and obtaining city population values are conducted. The airport locations are entered to QGIS software and the basic data has been indexed.

Step 2 is the accessibility analysis of airports by using QGIS software. Accessibility circles that have been determined in the diameter of $50 \mathrm{~km}, 75 \mathrm{~km}$ and $100 \mathrm{~km}$. The cities that have high accessibility to airports and the cities that have low accessibility to airports are determined. Thus, the airport necessity are obtained. The cities that have requirement for a better accessibility to airports are found.

In Step 3, the airport necessity and the passenger demand estimation have been found. Passenger demand estimation is made for the outsiders of $100 \mathrm{~km}$ diameter using estimated mobility numbers. Other properties such as spatial, social and economic properties are examined by multiple regression model and the meaningful variables have been utilized to determine the new airport locations.

\subsection{Study area}

Turkey is located between Asia and Europe and three sides of the country is surrounded by the sea. The capital city Ankara is located in the middle region of the country. The population is over 80 million and İstanbul, Ankara and Izmir is the most popular cities. The aviation sector is rapidly improving in the country. Moreover, Turkey may be leader in the related geographic region in near future due to its geographic location. Airport locations and the location of the country is given in Figure 2.

In domestic flights, about 10 years ago, there were only 26 accessible airport by Turkish Airlines. With the opening of new airports, seven airline companies started to fly to 55 destinations. Outer routes have flights to 268 destinations in 108 countries. The number of large-body aircraft in the airline fleet is close to 500 . The number of employees in the sector, which was around 65.000 in 2003 , now exceeds 200.000. In the last 10 years, the contribution of the sector's economy has reached to a level of 27 billion dollars from over 2.5 billion dollars. The number of passengers using airports across Turkey in 2003 reached an average of 30 million to 200 million [24]. 


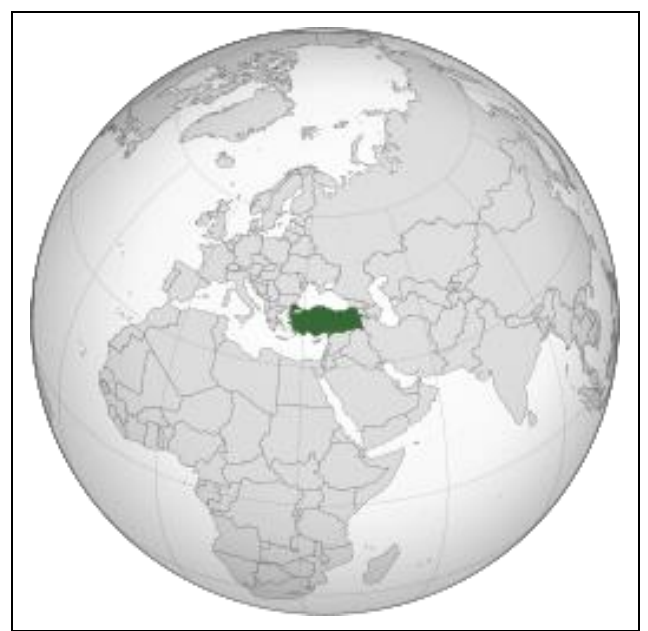

(a)

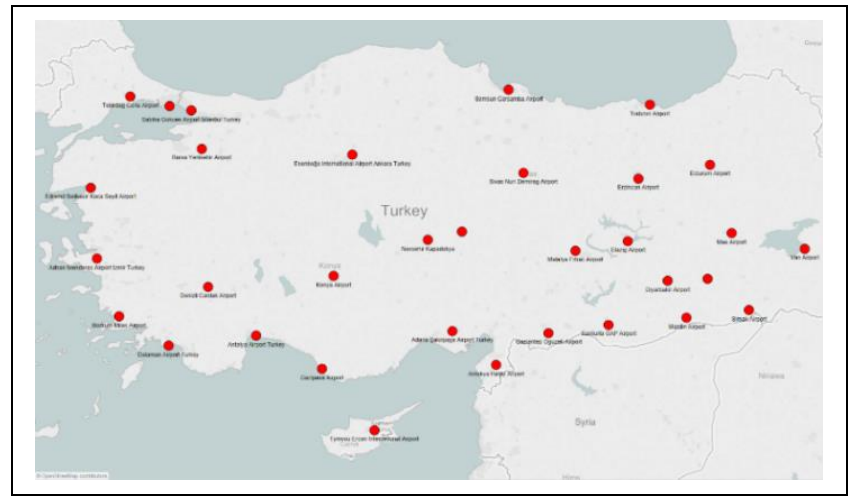

(b)

Figure 2(a): Location of Turkey. (b): Airport locations in Turkey [23].

\section{Analysis}

\subsection{Determining of airport accessibility}

By utilizing the software QGIS, 55 airports in Turkey is marked on the map. These airports are shown with 50, 75 and 100kilometer accessibility circles since the distances between cities in Turkey are approximately $300-400 \mathrm{~km}$. It was investigated which locations needed airports by considering accessible regions for the three different boundaries obtained. Figure 3 shows the coverage of 55 airport as a $50 \mathrm{~km}$ circular map in Turkey.

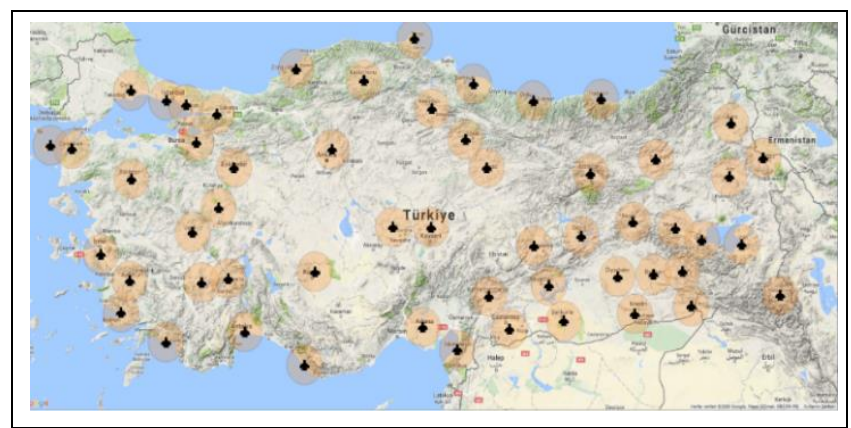

Figure 3: The coverage of 55 airport as a $50 \mathrm{~km}$ circular map by the QGIS.
To understand the wider accessibility possibilities Figure 4 shows the coverage of 55 airport as a $75 \mathrm{~km}$ circular map in Turkey. Figure 5 shows the coverage of 55 airport as a $100 \mathrm{~km}$ circular map in Turkey.

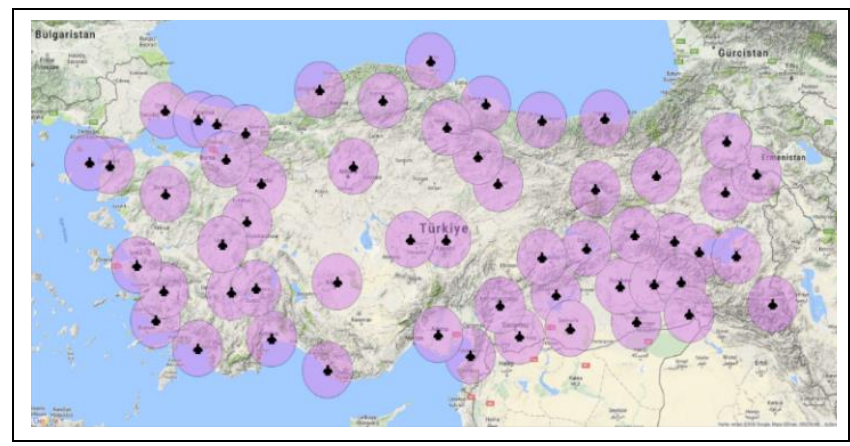

Figure 4: The coverage of 55 airport as a $75 \mathrm{~km}$ circular map by the QGIS.

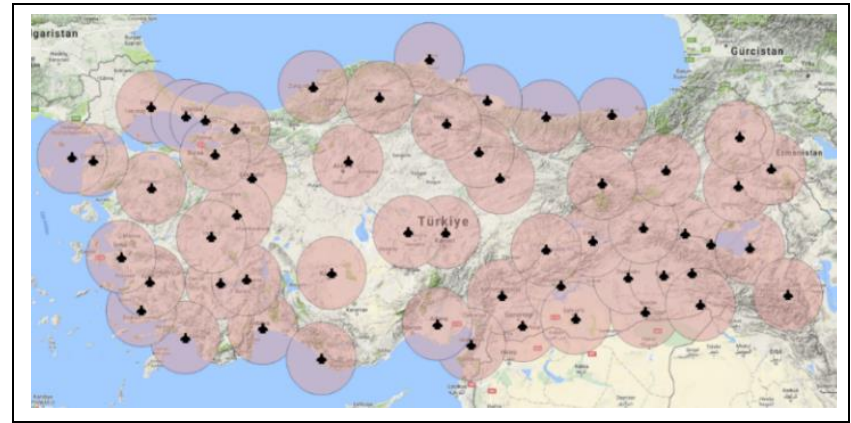

Figure 5: The coverage of 55 airport as a $100 \mathrm{~km}$ circular map by the QGIS.

The summary of the cities that is covered by the 50,75 and 100 $\mathrm{km}$ length of the airports centers are given in Table 1 . Twenty one cities with a total population of about 9 million people have not been an access to an airport within a $50 \mathrm{~km}$ length. Similarly, fourteen cities with a total population of about 3.5 million people have not been an access to an airport within a 75 $\mathrm{km}$ length. In addition, ten cities with a total population of about 2.5 million people have not been an access to an airport within a $100 \mathrm{~km}$ length.

In order to analyze the location airports and passengers demand, the domestic flights and passenger number are used. The obtained data for 50 active airports for which five of the airports are not active in 2017, in Turkey is given in Table 1. As can be seen in Figure 5, about 110 million passenger were used the 50 airports as domestic flights. As it is expected, the highest passenger is Istanbul and then Antalya Airport.

The population versus total number of domestic passengers for 2017 is given in Figure 6.

\subsection{Airport requirement and estimation of demand}

The correlation between the population and the airport passenger demand values for cities between 2010 and 2017 have been found. In order to find the passenger demand for airports the time series approach is used. Average passenger volumes of airport with reference to population may be determined. Correlation between the population and passenger demand is given in Figure 7. According to Figure 7, correlation between the population and passenger demand is may be interpreted as meaningful since $R^{2}=0.8291$ with the equation $y=$ 
$0.7913 x$-196782. $50 \mathrm{~km}, 75 \mathrm{~km}$ and 100 kilometers within the boundaries of circular areas are identified. The numbers of the cities that need the airport, and the capacities of the airports to be built are identified.
Table 2 shows the estimated (by regression analysis)annual number of passengers at airports which is for the $100 \mathrm{~km}$ lengths of airport coverage. The estimated passenger demand is obtained by averaging the number of total passengers to a total number of population. The mobility is obtained 0.55 and it is used for passenger estimations.

Table 1: The summary of the cities that are covered by the 50,75 and $100 \mathrm{~km}$ length of the airports centers.

\begin{tabular}{|c|c|c|c|c|c|}
\hline Out of $50 \mathrm{~km}$ access & Population (2017) & Out of $75 \mathrm{~km}$ access & Population (2017) & Out of $100 \mathrm{~km}$ access & Population (2017) \\
\hline Kırklareli & 278749 & Kırklareli & 278749 & Kırklareli & 278749 \\
\hline Edirne & 406855 & Edirne & 406855 & Edirne & 406855 \\
\hline Manisa & 1413041 & & & & \\
\hline Düzce & 377610 & Düzce & 377610 & Düzce & 377610 \\
\hline Bolu & 303184 & Bolu & 303184 & Bolu & 303184 \\
\hline Karaman & 246672 & Karaman & 246672 & Karaman & 246672 \\
\hline Çankırı & 186074 & Çankırı & 186074 & & \\
\hline Yozgat & 418650 & Yozgat & 418650 & & \\
\hline Corum & 528422 & & & & \\
\hline Osmaniye & 527724 & & & & \\
\hline Bayburt & 80417 & Bayburt & 80417 & Bayburt & 80417 \\
\hline Rize & 331041 & Rize & 331041 & & \\
\hline Gümüșhane & 170173 & Gümüșhane & 170173 & & \\
\hline Artvin & 166143 & Artvin & 166143 & Artvin & 166143 \\
\hline Ardahan & 97096 & Ardahan & 97096 & Ardahan & 97096 \\
\hline Aksaray & 402404 & & & & \\
\hline Niğde & 352727 & Niğde & 352727 & Niğde & 352727 \\
\hline Kırıkkale & 278749 & & & & \\
\hline Kırșehir & 234529 & Kurșehir & 234529 & Kırșehir & 234529 \\
\hline Mersin & 1793931 & & & & \\
\hline Karabük & 244453 & & & & \\
\hline Total $=$ & 8838644 & Total= & 3649920 & Total $=$ & 2543982 \\
\hline
\end{tabular}

Table 2: Population and estimated number of passenger values of cities that are covered by the $100 \mathrm{~km}$ length of the airports.

\begin{tabular}{ccc}
\hline Cities that are out of $100 \mathrm{~km}$ access & Population (2017) & Estimated Number of passengers (2017) \\
\hline Kirklareli & 278749 & 225517 \\
Edirne & 406855 & 209306 \\
Düzce & 377610 & 168053 \\
Bolu & 303184 & 136728 \\
Karaman & 246672 & 44575 \\
Bayburt & 80417 & 92092 \\
Artvin & 166143 & 53820 \\
Ardahan & 97096 & 195514 \\
Niğde & 352727 & 129998 \\
Kirșehir & 234529 & 1410110 \\
Total & 2543982 & \\
\hline
\end{tabular}

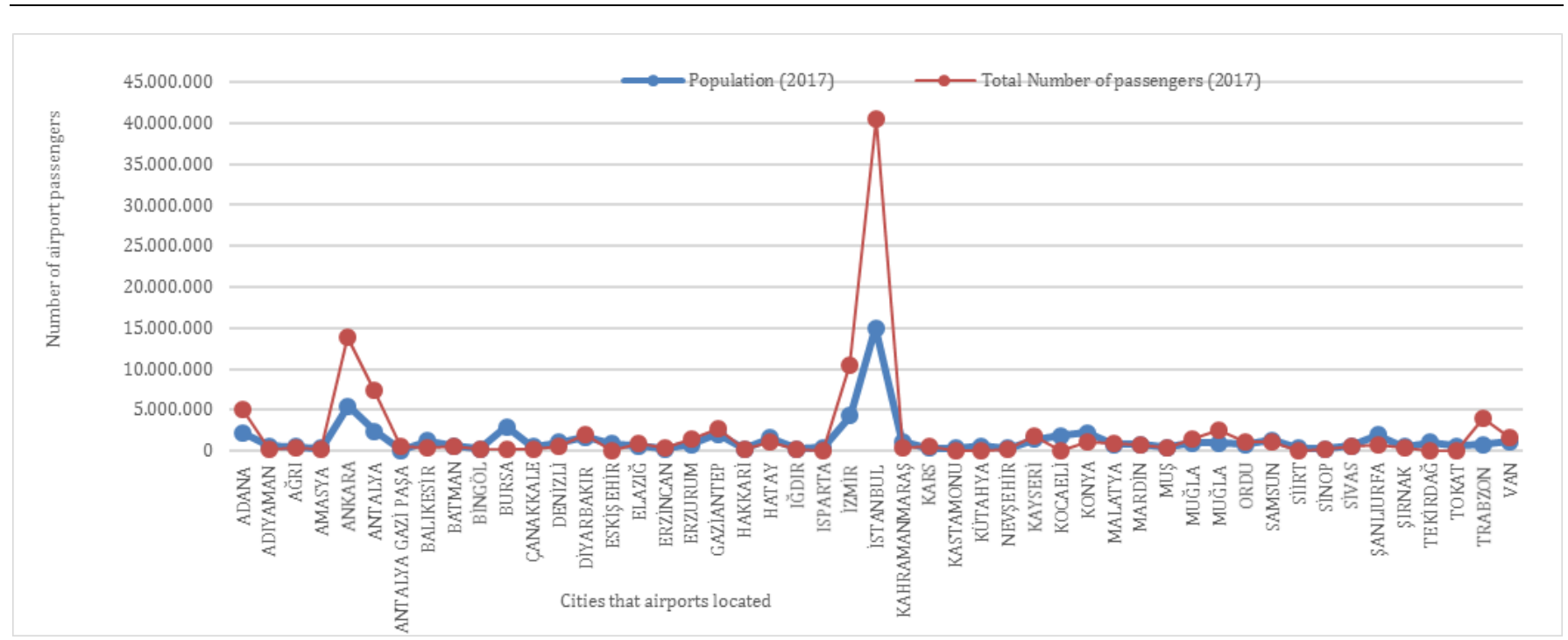

Figure 6: The population versus total number of domestic passengers for 2017. 


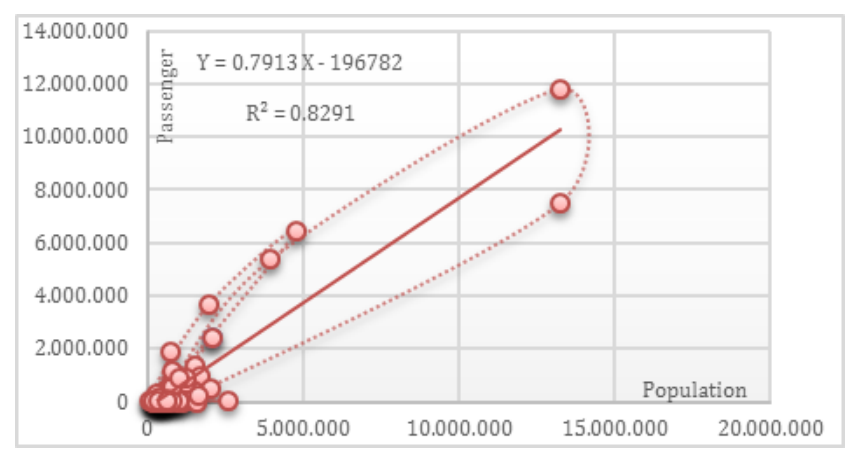

Figure 7: Correlation between the population and demand.

\subsection{Comparison of airport accessibility properties and other spatial, social and economic features}

Only the accessibility values did not evaluated. At the same time, other features of the cities with airports are investigated. The data collected in this research are population, number of enterprises registered in industrial registry, socio-economic development level and annual average daily traffic. The socioeconomic development level are examined in five categories as the most developed, developed, moderately developed, underdeveloped and least developed. Each category is graded between 1-5. Then, multiple regression analysis are conducted to investigate the relationship between the cities with airports and the four variables. The independent variables and the cities that do not have airport are given in Table 3.

As a result of the regression analysis, the statistics of the model and the significance levels of the variables were determined. According to the data obtained, high $\mathrm{R}^{2}$ indicates that the model has a high level of significance. When the independent variables are examined, it is seen that all variables are significant. At this point, especially the level of socio-economic development is remarkable. The significance level of the mentioned variable is two or even three times higher than the other variables. It is seen that the level of socio-economic development is significant in the location selection of airports. The results of regression analysis are given in Table 4.

Considering features of the cities that do not include airport in Turkey; Bolu, Edirne, Kırklareli, Manisa and Mersin have developed in terms of socio-economic level. When the accessibility levels of these cities are examined, it is seen that the accessibility levels of Bolu and Edirne are relatively low. On the other hand, the fact that Manisa and Mersin are at $75 \mathrm{~km}$ accessibility level and the high population amounts are remarkable. In these circumstances, in Turkey, the cities that airports may be constructed in the first place are considered as Bolu, Edirne, Manisa and Mersin.

Table 3: The independent variables and the cities that do not have airport [25]-[28].

\begin{tabular}{|c|c|c|c|c|c|}
\hline Cities & $\begin{array}{l}\text { Out of Access } \\
\text { Distance }\end{array}$ & Population & $\begin{array}{c}\text { Number of } \\
\text { Enterprises } \\
\text { Registered in } \\
\text { Industrial Registry }\end{array}$ & $\begin{array}{c}\text { Socio Economic } \\
\text { Development Level }\end{array}$ & $\begin{array}{l}\text { Annual Aver } \\
\text { Daily Traffi }\end{array}$ \\
\hline Aksaray & 75 & 412172 & 237 & Under Developed & 132472 \\
\hline Ardahan & 100 & 98907 & 28 & Least Developed & 31208 \\
\hline Artvin & 100 & 174010 & 42 & $\begin{array}{l}\text { Adequate } \\
\text { Developed }\end{array}$ & 65493 \\
\hline Bayburt & 100 & 82274 & 37 & Least Developed & 19059 \\
\hline Bolu & 100 & 311810 & 318 & Developed & 125189 \\
\hline Çankırı & 50 & 216362 & 150 & Under Developed & 151164 \\
\hline Çorum & 75 & 536483 & 418 & $\begin{array}{l}\text { Adequate } \\
\text { Developed }\end{array}$ & 191408 \\
\hline Düzce & 100 & 387844 & 424 & $\begin{array}{l}\text { Adequate } \\
\text { Developed }\end{array}$ & 179151 \\
\hline Edirne & 100 & 411528 & 244 & Developed & 122395 \\
\hline imüşhane & 50 & 162748 & 72 & Least Developed & 48979 \\
\hline Karabük & 75 & 248014 & 189 & $\begin{array}{l}\text { Adequate } \\
\text { Developed }\end{array}$ & 118021 \\
\hline Karaman & 100 & 251913 & 218 & $\begin{array}{l}\text { Adequate } \\
\text { Developed }\end{array}$ & 55386 \\
\hline Kırıkkale & 100 & 286602 & 214 & $\begin{array}{l}\text { Adequate } \\
\text { Developed }\end{array}$ & 234167 \\
\hline Kurklareli & 75 & 286602 & 266 & Developed & 117296 \\
\hline Kırşehir & 100 & 241868 & 110 & $\begin{array}{l}\text { Adequate } \\
\text { Developed }\end{array}$ & 92793 \\
\hline Manisa & 75 & 1429643 & 1230 & Developed & 688212 \\
\hline Mersin & 75 & 1814468 & 1139 & Developed & 285051 \\
\hline Niğde & 100 & 364707 & 178 & Under Developed & 82812 \\
\hline smaniye & 75 & 534415 & 253 & Under Developed & 67229 \\
\hline Rize & 50 & 348608 & 217 & $\begin{array}{l}\text { Adequate } \\
\text { Developed }\end{array}$ & 157663 \\
\hline Yozgat & 50 & 424981 & 190 & Under Developed & 111176 \\
\hline
\end{tabular}


Table 4: Regression statistics.

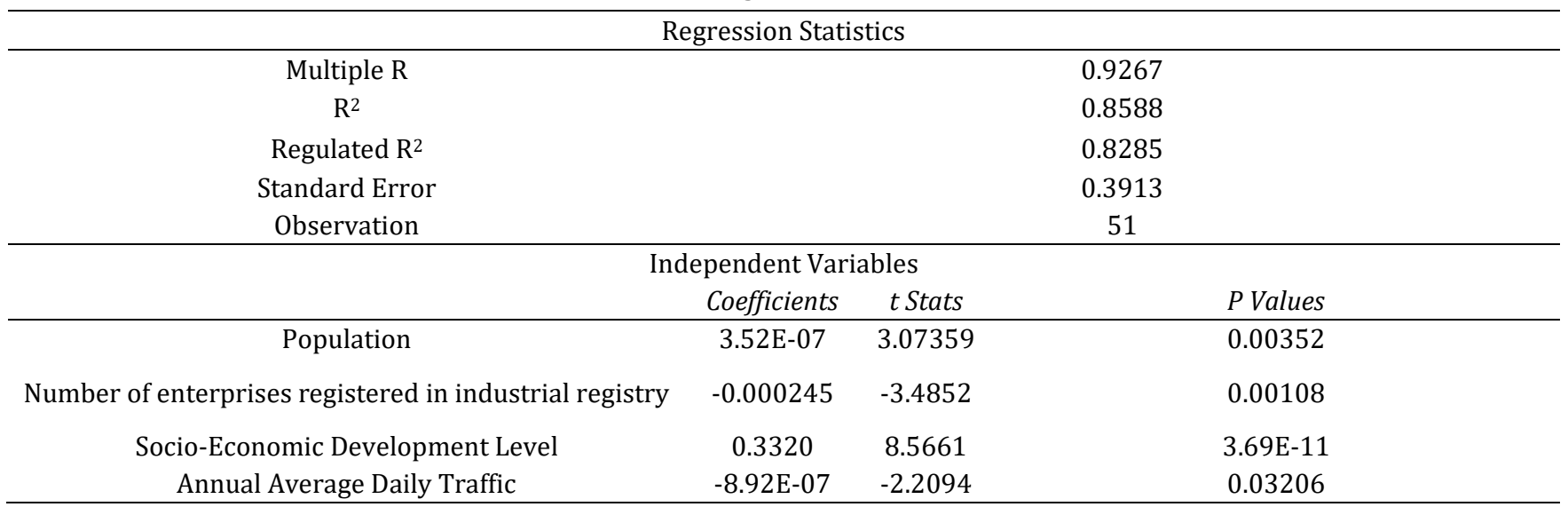

\section{Conclusions}

This study investigates the airport coverage of the Turkey for 50,75 and $100 \mathrm{~km}$ circular lengths. The following results may be drawn from this study. The access of the airports may affects the passenger demands, so this study investigate the Turkish airport coverage in length of 50,75 and $100 \mathrm{~km}$ radius from city centers. Results showed that if $100 \mathrm{~km}$ radius length is used as a criterion for building new airport, only 10 cities with total population of about 2.5 million with an estimated values of about 1.4 million airport passenger will be outside the airport access. The main findings this study is that there are no new airport are not needed to newly be constructed since only 10 of the city is not covered by the $100 \mathrm{~km}$ length. The 10 of the cities access to nearest airport may be supported by the High Speed rail such as Bayburt, Corum, Edirne etc. Accessibility properties are compared with the special properties of the cities and possible new airport locations have been determined. Results show that, the cities that may be constructed as airports in the first place can be considered as Bolu, Edirne, Manisa and Mersin.

Note that, this study determine the cities, which requires airport facilities in terms of accessibility and some mentioned specifications. However, in future airport location selection studies, it is necessary to consider adequate status parameters for aviation activities, environmental development, atmospheric conditions, access to land transport, topography, environment, runway length, number and direction that are not included in this study.

\section{References}

[1] Keskin H. Lojistik-Tedarik Zinciri Yönetimi (Gecmişi, Degișimi, Bugünü, Geleceği). İstanbul, Türkiye, Nobel Akademik Yayıncılık Eğitim Danışmanlık Tic. Ltd. Şti., 2009.

[2] Özgen H. "Lojistik ve Ulaştirma İlişkisi. Miymed Eğitim". https://www.biymed.com/ (09.11.2018).

[3] Kurt C. The Significance of Logistics in Transport Sector in Turkey. MSc Thesis, Istanbul University, Istanbul, Turkey, 2010.

[4] Evliyaoglu D, Tezel E. "Evaluation of interior spaces of airport buildings for accessibility of visually and physically disabled people: a case study of Istanbul Atatürk Airport". Journal of Engineering Sciences and Design, 5, 95-108, 2017.
[5] Litman T. "Evaluating Accessibility for Transportation Planning". Victoria Transport Policy Institute, Canada, 2010.

[6] Reichmuth J. "Analyses of the European air transport market, Airport Accessibility in Europe". European Comission, Köln, Germany, Scientific Report, 2010. https://ec.europa.eu/transport/sites/transport/files/mo des/air/studies/doc/intermodality/2010-airportaccessibility-in-eu.pdf

[7] Pels E, Nijkamo P, Rietveld P. "Airport choice in a multiple airport region". Journal of Urban Economics, 48, 29-45, 2000.

[8] Pels E, Nijkamo P, Rietveld P. "Airport choice in a multiple airport region, an empirical analysis fort he San Francisco Bay area". Regional Studies, 35, 1-9, 2001.

[9] Kanafani A, Gosling G, Thaghave S. "Studies in the demand for short-haul air transportation". Institute of Transportation and Traffic Engineering, California, USA, Special Report, 1975.

[10] De Neufville R. Guessing at the Future. Cambridge, England, 1976.

[11] De Neufville R. "Planning for multiple airports in a metropolitan region". Built Environment, 10(3), 159-167, 1984

[12] Ashford N, Benchemam M. "Passengers' choice of airport, an application of the multinomial logit model". Transportation Research Record, 1147, 1-5, 1987.

[13] Harvey G. "Airport choice in a multiple airport region". Transport Research, 21A (6), 439-449, 1987.

[14] Thompson M., Caves R. "The projected market share for a new small airport in the North of England". Regional Studies, 27 (2), 137-147, 1993.

[15] Derruder B., Devriendt L., Witlox, F. "A spatial analysis of multiple airport cities". Journal of Transport Geography, 18(2010), 345-353, 2010.

[16] Min H, Melachrinoudis E, Wu X. "Dynamic expansion and location of an airport: A Multiple objective approach". Transportation Research-Part A, 31(5), 403-417, 1997.

[17] Yang Z, Yu S, Notteboom T. "Airport location in multiple airport regions (MARs): The role of land and airside accessibility". Journal of Transport Geography, 52, 98-110, 2016.

[18] Cohas FJ, Belobaba PP, Simpson RW. "Competitive fare and frequency effects in airport market share modelling". Journal Air Traffic Management, 2(1), 33-45, 1995. 
[19] Loo BPY, Ho HW, Wong SC. "An application of the continuous equilibrium modelling approach in understanding the geography of air passenger flows in a multi-airport region". Applied Geography, 25(2), 169-199, 2005.

[20] Avci T, Aktaş M. "Performance Evaluation of the Airports Operating in the Turkey". International Journal of Alanya Faculty of Business, 7(3), 67-77, 2015.

[21] ICAO, International Civil Aviation Organization. "Airport Planning Guide, First Section Master Planning". Montreal, Canada, Scientific Report, 73-95, 1987.

[22] Arabacı G. Havaalanı Yerseçiminde ve Çevre Düzenlemesinde Vahşi Yaşamın Etkileri”. Yüksek Lisans Tezi, Gazi Üniversitesi, Ankara, Türkiye, 2010.

[23] Turkey Airport Maps. http://www.planeflighttracker.com/2014/05/turkeyairports-map.html (05.04.2019).
[24] Emlak Kulisi, https://emlakkulisi.com/5-yenihavalimani-insa-edilecek/378528 (05.03.2019).

[25] TÜİK. "Yllara Göre İl Nüfusları Erișim Adresi" https://www.tuik.gov.tr (01.11.2018).

[26] Sanayi ve Teknoloji Bakanlığı. "81 İl Sanayi Durum Raporu". Ankara, Türkiye, 2019.

[27] Özceylan D, Coşkun E. "Türkiye'deki illerin sosyoekonomik gelişmişlik düzeyleri ve afetlerden sosyal ve ekonomik zarar görebilirlikleri arasindaki ilişki". Istanbul University Journal of the School of Business Administration, 41(1), 31-46, 2012.

[28] Trafik Güvenliği Dairesi Başkanlığı Ulaşım Etütleri Şubesi Müdürlüğü. "Otoyollar ve Devlet Yollarının Trafik Dilimlerine Göre Yıllık Ortalama Günlük Trafik Değerleri ve Ulaşım Bilgileri Raporu”. 2014. 